\title{
RELATIONSHIP BETWEEN HANDWASHING HABITS WITH DIARHEA INCIDENT IN CHILDREN UNDER TWO YEARS
}

\author{
HUBUNGAN ANTARA KEBIASAAN MENCUCI TANGAN \\ DENGAN INSIDEN DIARE PADA ANAK DI BAWAH DUA TAHUN
}

\author{
Shintia Yunita Arini ${ }^{1 *}$, Nala Astari Pramesti ${ }^{1}$, Dian Prasasti ${ }^{2}$, Isas Awwalina ${ }^{1}$ \\ ${ }^{1}$ Department of Occupational Health and Safety, Faculty of Public Health, Universitas Airlangga \\ Jl. Mulyorejo No. 4760115 Surabaya, East Java, Indonesia \\ ${ }^{2}$ Department of Epidemiology, Faculty of Public Health, Universitas Airlangga Jl. Mulyorejo No. 47 \\ 60115 Surabaya, East Java, Indonesia \\ *email: shintia.arini@fkm.unair.ac.id
}

\begin{abstract}
Diarrhea in children under five based on diagnosis and symptom occurred in $18.5 \%$ of children in 2018 and $12.3 \%$ of children in 2013, indicating an increase. According to the health profile of Bojonegoro Regency of 2018, out of 33,667 diarrhea cases reported, 31,010 or $92.11 \%$ of them were treated. This study aims to analyze the relationship between handwashing practice, use of latrine and SPAL (sewerage) with diarrhea incidents in Bojonegoro Incidents. This study used observational study design with cross-sectional approach. Samples in this study were 63 toddlers spread across 4 villages taken using proportional random sampling technique. The collection of primary data was performed by interviewing and observing mothers that had toddlers. Chi square test method was used to determine the relationship between variables examined, where diarrhea occurred in children under five if $p<\alpha(\alpha$ margin of error $=0.05)$. The results of the study conducted from December 27, 2019 to January 31, 2020 showed that there was a significant relationship between handwashing habit and diarrhea incidents in toddlers, with $\mathrm{p}=0.000$. There was no significant relationship between latrine condition and diarrhea in toddlers, with $\mathrm{p}=0.808$. Furthermore, there was no significant relationship between SPAL condition and diarrhea incidents in toddlers, with $\mathrm{p}=0.085$. There was a significant relationship between handwashing habits in mothers that had children under two with diarrhea incidents.
\end{abstract}

Keywords: Diarrhea, Handwashing, Latrine

\section{INTRODUCTION}

Health is a basic human right. According to $\mathrm{WHO}$, a person is considered healthy if they are free from diseases or disability and are well physically, mentally and socially. One of the most common health problems in Indonesia is diarrhea. Diarrhea is a condition of having liquid or watery bowel movements more than three times each day. Diarrhea incidents based on diagnosis and symptoms in Indonesia showed a prevalence rate of $8 \%$, up from $7 \%$ in 2013 , while diarrhea incidents in children under five were $18.5 \%$ in 2018 and $12.3 \%$ in 2013, indicating an increase (Riskesdas, 2018). According to the health profile of Bojonegoro Regency of 2018, out of 33,667 diarrhea cases reported, 31,010 or $92.11 \%$ of them were treated. Clinically, the causes of diarrhea can be grouped into 6 major categories, namely infections (caused by caused by bacteria, viruses or parasitic infestations, malabsorption, allergies, poisoning, immunodeficiency and other causes. The most common causes observed in the field were infections and poisoning (Kemenkes, 2011).

Diarrhea incidents are closely associated with basic sanitation condition and clean and healthy life behavior. Basic sanitation includes clean water, drinking water source, latrine condition, sewerage, and flooring types. There are some requirements for a healthy latrine, 
namely unpolluted drinking water sources, the distance of septic tank from the drinking water source of about 10 to 15 meters, odorless and feces that are unreachable by vectors, sloping and fairly spacious or tilted towards the squat hole so as not to contaminate surrounding soils, easy to clean and safe to use, having walls and roof that shelter from water, adequate illumination and good ventilation (Rohmah and Syahral, 2017). Poor wastewater management may also negatively impact public health because it may result in the transmission of various diseases, in this case is diarrhea. One effort that can be done is by building a closed sewerage (SPAL) and always maintaining SPAL sanitation so that there is no inundation which is a medium of diarrheal transmission. In addition to sanitation aspect, diarrhea can also be caused by poor and unhealthy hygiene and lifestyle (Langit, 2016).

Healthy, hygienic lifestyle may start from the simplest habit of handwashing. This most ignored healthy habit is surprisingly influential to public health due to the fact that various transmissions are the result of hand contact such as a handshake or handing things over, eating food with hands or touching eyes or nose. The habit of washing hands without soap and running water is worryingly common. Many people do not realize the importance of handwashing with soap for health (Kemenkes, 2011).

Bad handwashing habits such as not washing your hands before eating, but after eating, and not washing your hands after using the toilet are still common. Washing hands with soap is shown to consistent reduce the risk of diarrhea and respiratory diseases (Luby, et al, 2009). The purpose of this study was to analyze the relationship between latrine conditions and diarrheal incidents, analyze the relationship between SPAL and diarrheal incidents and analyze the relationship between hand washing and diarrhea in Bojonegoro Regency because the incidents of diarrhea in the area was still high.

\section{RESEARCH METHODS}

This study used an observational research design with a cross-sectional approach, which studies the relationship between exposure and disease by observing the status of both simultaneously (measured at the same time) on individuals or units of observation of a single population at a particular time. The study population was all families with toddlers (children under two years old) in Leran Village, Bojonegoro, amounting to 357 respondents. The samples taken were 63 toddlers spread across 4 villages selected using proportional random sampling technique.

The study was conducted after an ethical review by the ethics committee. After being declared ethically feasible, the research could be carried out immediately. The collection of primary data was performed by interviewing mothers that had toddlers, and observing latrines and sewerages in households after the respondents signed an informed consent form. Questions contained in the questionnaire included hand washing habits, latrine conditions, ownership of closed SPALs and the incidents of diarrhea. The secondary data was obtained from medical records on illnesses events suffered by under toddlers and the profile of the Pungpungan Health Center in Bojonegoro Regency. The operational definition for handwashing habit variables was washing hands with soap and washing hands without soap. For SPAL variables, they were defined by whether it was closed or open. While latrine conditions were defined by healthy and unhealthy latrines. The criteria included in the operational definition for healthy latrines were closed latrine construction, have a strong and non-slippery floor and footing, no foul odor, no visible dirt, septic tank distance of $\geq 10$ meters, no insects roaming around, and the availability of cleaning tools. The data obtained were analyzed using univariate analysis and bivariate analysis. The bivariate analysis was performed using the chi square test method to determine the relationship between variables investigated and diarrheal incidents in children under five, where it occurred if $\mathrm{p}<\alpha$ (margin of error $\alpha=0.05$ ). The results of analysis were presented in tabular and narrative form.

\section{RESULTS AND DISCUSSION}

The results of the characteristic assessment of mothers with toddlers include the level of mother's education and mother's occupation, which are presented in Table 1 . Education level characteristic in Table I showed that the majority of the respondents $(30.2 \%)$ finished elementary (SD) and high school (SMA), followed by those who finished junior high school with $25.4 \%$, those who graduated from higher education with $7.9 \%$, and those who did not go to school with $6.3 \%$.

The majority of the mothers with toddlers were housewives (not working) with 
$58.7 \%$, while $41.3 \%$ of them had a job. The majority of them $(52.4 \%)$ washed hands with soap while $47.6 \%$ of them washed hands without soap. Table 1 also showed nearly all of them (71.4\%) had a healthy latrine and $28.6 \%$ of them did not. The SPAL conditions in the respondents showed that $71.4 \%$ of them had an open latrine while $28.6 \%$ of them had a closed one.

Table 1. Mother Characteristics and House Conditions

\begin{tabular}{lrr}
\hline \multicolumn{1}{c}{ Variables } & n & \% \\
\hline Education Level & & \\
No School/TT SD & 4 & 6.3 \\
SD & 19 & 30.2 \\
SMP & 16 & 25.4 \\
SMA & 19 & 30.2 \\
PT & 5 & 7,9 \\
Total & 63 & 100 \\
Job & & \\
Employed & 26 & 41.3 \\
$\quad$ Housewives & 37 & 58.7 \\
Total & 63 & 100 \\
Handwashing Habits & & \\
$\quad$ With soap & 33 & 52.4 \\
$\quad$ Without soap & 30 & 47.6 \\
Total & 63 & 100 \\
Latrine Conditions & & \\
$\quad$ Healthy & 45 & 71.4 \\
Unhealthy & 18 & 28.6 \\
Total & 63 & 100 \\
SPAL Conditions & & \\
Closed & 18 & 28.6 \\
Open & 45 & 71.4 \\
Total & 63 & 100 \\
\hline B & &
\end{tabular}

Based on Table 2, 90.91\% of toddlers of the mothers who wash their hands using soap were not affected by diarrhea, while $76.67 \%$ of toddlers of the mothers who had the habit of washing their hands without soap were affected by diarrhea. Based on the statistical test using chi square, a $p$-value $<0.05$ of 0.000 . This showed that there was a significant relationship between handwashing habits and diarrhea incidents in toddlers.

The majority of the respondents $(57.8 \%)$ who used healthy latrines had toddlers who were not affected by diarrhea. While respondents who used unhealthy latrines $(41.2 \%)$ have toddlers who were not affected by diarrhea. According to the results in Table 2, chi-square test obtained a $p$-value $>0.05$ of 0.808 . This showed that there was no significant relationship between latrine conditions and diarrhea incidents in toddlers.

The people that had a closed SPAL showed a similar rate of diarrhea and no diarrhea events of $50 \%$. Whereas for open SPAL, the majority $(62.3 \%)$ of their toddlers were not affected by diarrhea. Based on Table II, chisquare test obtained a $p$-value $>0.05$ of 0.085 . This showed that there was no significant relationship between SPAL conditions and diarrhea incidents in toddlers. The results obtained by researchers from the study in December 2019-January 2020 in Bojonegoro indicated the occurrence of diarrhea. This was attributable to basic sanitation and clean and healthy lifestyle (PHBS) of the mothers.

Tabel 2. Comparison Related Factors of Diarhea among Children Under Two Years

\begin{tabular}{cllll}
\hline \multirow{2}{*}{ Variables } & \multicolumn{2}{c}{ Diarrhea } & \multirow{2}{*}{ Total } & \multirow{2}{*}{$\mathbf{p}$} \\
\cline { 2 - 3 } & \multicolumn{1}{c}{$\mathbf{n}(\boldsymbol{\%})$} & $\mathbf{n}(\boldsymbol{\%})$ & $\mathbf{n}(\%)$ & \\
\hline Handwashing & & & & \\
With soap & 3 & 30 & 33 & \\
& $(9.09)$ & $(90.91$ & $(100)$ & \\
Without soap & 23 & ) & 30 & \\
& $(76.6)$ & 7 & $(100)$ & 0.000 \\
Total & 26 & $(23.4)$ & 63 & \\
& $(41.2)$ & 37 & $(100)$ & \\
Latrine & & $(58.8)$ & & \\
Healthy & 19 & 26 & 45 & \\
& $(42.2)$ & $(57.8)$ & $(100)$ & \\
Unhealthy & 7 & 11 & 18 & \\
& $(38.8)$ & $(61.1)$ & $(100)$ & 0.808 \\
Total & 26 & 37 & 63 & \\
& $(41.2)$ & $(58.8)$ & $(100)$ & \\
SPAL & & & & \\
Closed & 9 & 9 & 18 & \\
& $(50)$ & $(50)$ & $(100)$ & \\
Open & 17 & 28 & 45 & 0.085 \\
& $(37.7)$ & $(62.3)$ & $(100)$ & \\
Total & 26 & 37 & 63 & \\
& $(41.2)$ & $(58.8)$ & $(100)$ & \\
\hline
\end{tabular}

The level of education may influence the mothers in receiving information and knowledge. The mothers with good education levels are able to receive and process information from both print and electronic media with more ease than the mothers with low education levels. Low education levels will make it difficult for the mothers to receive and process information about the importance of clean and healthy behavior to prevent diarrheal incidents, so the mothers seemed unconcerned about prevention efforts. The information gained by these mothers should be used as a guidance for the mothers to care for their children in everyday life.

The higher a person's education level, the easier for them to change their handwashing habits, in this case is the mothers with high school education. High school education has exceeded nine years of elementary education, 
and the mothers are most likely to be better at receiving information and have good knowledge, which translate to good handwashing habits (Alhidayah, 2015). This was in line with the study by Numaliza \& Herlina (2018) stating that parents' education is one of the important factors in nutritional status because good education makes parents easily accept and process external information on how to raise children, especially with regard to how to give food to children, how to maintain children's health and provide education (Nazila and Herlina, 2018).

Mother's employment status influences parenting style. Mothers who stay at home can optimally control and care for their children, especially in terms of nutritional intake (Rohmah and Syahrul, 2017). This was in line with the study by Lailatul \& Ni'mah (2015) stating that mothers with good parenting tend to have toddlers with better nutritional status than mothers with poor parenting (Lailatul and $\mathrm{Ni}$;mah, 2015). The findings in the study were that mothers with toddlers mostly worked as farmers who work from morning to evening, thus, having very little time for their children. When the mothers were at work, the toddlers were at home cared for by his grandmother and other relatives.

\section{The Relationship between Handwashing Habits and Diarrheal Incidents in Toddlers}

Based on the results of statistical tests that have been carried out, there is a significant relationship between handwashing habits and the diarrhea incidents in toddlers, in line with the theory proposed by Utomo (2013) demonstrating that there was a relationship between washing hands with soap (CTPS) and diarrheal incidents in children, where the better the habit of washing hands with soap, the lower the diarrheal incidents would be (Utomo,et al., 2013). Conversely, the poorer the handwashing habits are, the higher the diarrheal incidents will be. Washing hands with soap is a part of healthy living behavior. Proper handwashing properly is not only influenced by the way of the washing, but also by the water and the wipe rag used. Washing hands with soap is a preventive measure against diseases transmitted through hand contact such as diarrhea and upper respiratory tract infection (Purwandari, et al., 2013). The results showed that the majority of the respondents did not provide a dedicated soap for washing hands at home and they believed that washing hands with only water is just as clean.

\section{The Relationship between Latrine Conditions and Diarrheal Incidents in Toddlers}

Based on the results of statistical tests, no significant relationship was found between latrine conditions and diarrhea incidents in toddlers. This was not in line with the theory expressed by Utama et al. (2019) demonstrating that there was a relationship between household latrine condition and diarrheal incidents in toddlers. (Utama, et al, 2019). Subpar household latrine condition might lead to diarrheal event in toddler respondents because feces that are not properly and deeply buried will invite flies and mice which will have an impact on environmental health.

Unclean latrines will attract animals that are a mechanical vector of various infectious diseases including diarrhea. Latrine is one of the important sanitation facilities and is closely associated with diarrhea. Substandard fecal disposal sites will increase the risk of diarrhea by 2.55 times compared to households who dispose feces in a sanitary manner (Ifandi, 2017). Thus, the provision of a household latrine in a community, particularly in its implementation, is not a trivial matter. Therefore, synergistic cooperation between the community and the government is needed in an effort to improve environmental sanitation.

\section{The Relationship between SPAL conditions and Diarrheal Incidents in Toddlers}

Based on the results of statistical tests, there was no significant relationship between the condition of SPAL and diarrheal incidents in toddlers. This was not in line with the theory expressed by Saleh \& Rachim (2014) demonstrating that there was a relationship between sewerage and diarrheal incidents. Sewerage has a very important impact on people's lives. Improper placement, construction and management of it may end up spreading bacteria and viruses that cause disease (Saleh and Rachim, 2014).

Poor wastewater management can adversely affect public health and the environment because this can be a medium of transmission or spread of various diseases, especially diarrhea (Langit, 2016). Thus, to prevent or mitigate waste water contamination to the environment, waste must be managed properly so that it does not become a breeding 
ground for diseases such as flies, does not pollute groundwater sources and does not radiate odors.

\section{CONCLUSION}

Based on the results of the study conducted in Leran Village, Kalitidu District, Bojonegoro Regency on December 27, 2019 to January 31,2020 by distributing a questionnaire containing questions related to PHBS indicators and basic sanitation that includes handwashing, latrine conditions and SPAL conditions, it can be concluded that (i) there was a significant relationship between handwashing habits and diarrheal incidents in toddlers; (ii) There was no significant relationship between latrine conditions and diarrheal incidents in toddlers; (iii) There was no significant relationship between SPAL conditions and diarrheal incidents in toddlers.

\section{REFERENCES}

1] Riskesdas K. Hasil Utama Riset Kesehata Dasar (RISKESDAS). J Phys A Math Theor [Internet]. 2018;44(8):1-200. Available from:

http://arxiv.org/abs/1011.1669\%0Ahttp://dx .doi.org/10.1088/1751-

8113/44/8/085201\%0Ahttp://stacks.iop.org/ $1751-$

$8121 / 44 / \mathrm{i}=8 / \mathrm{a}=085201$ ?key=crossref.abc74 c979a75846b3de48a5587bf708f

2] Kemenkes RI. Situasi diare di Indonesia. J Bul Jendela Data Inf Kesehat. 2011;2:1-44.

3] Rohmah N, Syahrul F. Hubungan Kebiasaan Cuci Tangan Dan Penggunaan Jamban Sehat Dengan Kejadian Diare Balita. J Berk Epidemiol. 2017;5:95-106.

4] Langit LS. Hubungan Kondisi Sanitasi Dasar Rumah Dengan Kejadian Diare Pada Balita Di Wilayah Kerja Puskesmas Rembang 2. J Kesehat Masy. 2016;4(2):160-5.

5] Luby SP, Aeboatwalla M, Bowen A, Kenah E, Sharker Y, Hoekstra RM. Difficulties in maintaining improved handwashing behavior, Karachi, Pakistan. Am J Trop Med Hyg. 2009;81(1):140-5.

6] Alhidayah NS. Hubungan Kebiasaan Cuci
Tangan dengan Perilaku Ibu dalam Pencegahan Diare pada Balita di Puskesmas Gamping 1 Yogyakarta. 2015.

7] Numaliza N, Herlina S. Hubungan Pengetahuan dan Pendidikan Ibu terhadap Status Gizi Balita. KESMARS J Kesehat Masyarakat, Manaj dan Adm Rumah Sakit. 2018;1(1):44-8.

8] Lailatul M, Ni'mah. C. Hubungan Tingkat Pendidikan, Tingkat Pengetahuan dan Pola Asuh Ibu dengan Wasting dan Stunting pada Balita Keluarga Miskin. Media Gizi Indones [Internet]. 2015;10(2015):84-90. Available from: https://ejournal.unair.ac.id/MGI/article/download/3 $131 / 2288$

9] Utomo AM dkk. Hubungan Perilaku Cuci Tangan Pakai Sabun (CTPS) Dengan Kejadian Diare Anak Usia Sekolah Di Sdn 02 Pelemsengir Kecamatan Todanan Kabupaten Blora. J Keperawatan. 2013;6(1):1-10.

10] Purwandari R, Ardiana A, Wantiyah. Hubungan antara Perilaku Mencuci Tangan dengan Insiden Diare pada Anak Usia Sekolah di Kabupaten Jember. Keperawatan Univ Jember. 2013;4(2):122-30.

11] Utama SYA, Inayati A, Sugiarto $S$. Hubungan Kondisi Jamban Keluarga Dan Sarana Air Bersih Dengan Kejadian Diare Pada Balita Di Wilayah Kerja Puskesmas Arosbaya Bangkalan. Din Kesehat J Kebidanan Dan Keperawatan. 2019;10(2):820-32.

12] Ifandi S. Hubungan Penggunaan Jamban dan Sumber Air dengan Kejadian Diare pada Balita di Kecamatan Sindue The Relationship of Toilet Utilization and Water Resources Utilization to the Occurrence of Diarrhea in Infants in Sindue District of Donggala Regency, Central. 2017;2(2):3844.

13] Saleh M, Rachim LH. Hubungan Kondisi Sanitasi Lingkungan dengan Kejadian Diare pada Anak Balita di Wilayah Kerja Puskesmas Baranti Kabupaten Sidrap. J Kesehat. 2014;VII(1):221-33. 